\title{
THE GOVERNMENT AUDITOR PROFESSIONALISM DETERMINANT
}

\author{
I Gusti Ayu Purnamawati \\ Universitas Pendidikan Ganesha \\ ayupurnama07@yahoo.com \\ Ni Ketut Sari Adnyani \\ Universitas Pendidikan Ganesha \\ sariadnyani@yahoo.co.id
}

Received: December, 2018

Revisied: April, 2019

Accepted: April, 2019

\section{ABSTRACT}

The aim of this study was to analyze the professionalism of the government auditors in Bali Province. This study is an explanatory research. The samples of this study were 30 respondents. The subjects of this study were all auditors at the Inspectorate of Buleleng Regency, Inspectorate of Denpasar City and Inspectorate of Bali Province. Types of data used was quantitative data, while the data collected by using questionnaires. Data analysis methods used were validity and reliability test, the classical assumption, and the hypothesis were tested using F-test analysis and t-test analysis which were then analyzed using multiple linear regression analysis. All the variables in this study were measured using the likert scale 1-5. The results showed that Motivation, Work Culture, Leadership Style, Gender, and Independence had positive and significant impact on the professionalism of the government auditors. An internal government auditor should improve his professionalism for the efficiency and effectiveness improvement in order to improve public sector performance.

Keywords: Auditor, Government, Professionalism.

How to cite: Purnamawati, I.G.A \& Adnyani, N.K.S. (2019). The Government Auditor Professionalism Determinant. Akrual: Jurnal Akuntansi. 10 (2): 105-118. doi: http://dx.doi.org/10.26740/jaj.v10n2.p105-118

\section{INTRODUCTION}

Internal Audit is one of the elements which contributes most to the implementation of governance. This is consistent with the statement that the effectiveness of the GIA is important in order to establish good governance and also with the scope of internal audit defined by the Institute of Internal Auditors Research Foundation, where internal audit activity is expected to improve the effectiveness of risk management, control and governance of an organization (Santosa, et al., 2016), (Norgren,
2010). The Internal Audit Competency Framework (IIARF, 2013) has identified three key area of expertise: the international professional practices framework; governance, risk, and control; and business acumen (D’Onza \& Sarens, 2018). Some studies demonstrate positive correlations, other insignificant or negative correlations between auditing and better public sector performance (Carlson, et al., 2013); (Rutherford, 2014). Research (Soh \& Martinov-Bennie, 2011), suggest significant expansion and refocus of the role of internal 
AKRUAL: Jurnal Akuntansi, volume 10, issue 2, April 2019 (105-118)

audit and perceptions of its effectiveness.

However, the findings also suggest that performance evaluation mechanisms of internal audit have not evolved contemporaneously. The misalignment between the role and evaluation gives rise to difficulty in assessing the extent to which internal audit functions are meeting stakeholders' expectations. In the performance of audit tasks, an auditor is responsible for the planning and execution of the audit in order to obtain reasonable assurance whether the financial statements are free from material missstatements or not. Auditor profession is based on trust because it carries the confidence of the community in performing its duties by upholding independence, integrity, honesty, objectivity, and professionalism. Auditors' failure to detect risk from material misstatements within financial statements has a negative impact on the audit profession in general (Hussin, et al., 2017). Ethical behavior is needed by the community so that everything can run on a regular basis.

Every profession that provides services to the public must have a code of ethics which is a set of moral principles that regulate professional behavior. Although professional standards and codes of ethics have been established, there are still frequent cases of collusion and corruption or misappropriation. An auditor is always required to have professionalism in performing their duties. Auditor professionalism is the attitude and behavior of the auditors in carrying out their profession with seriousness and responsibility in order to achieve task performance as regulated 106 in professional organization, covering dedication to profession, social obligation, independence, professional belief, and relationship with colleagues (Herawaty \& Susanto, 2009). Professionalism is needed to improve the audit quality in order to prevent, detect, and reveal fraud.

Motivation is a factor that has an important role for improving the performance of auditors, where self-motivation is very important role in encouraging someone to work professionally and perform certain activities to achieve a goal that is a good quality audit, because with motivation, the individuals will work with enthusiasm to achieve the expected work. Intrinsic motivation is generally thought to be positively associated with performance on a variety of tasks; however, there is only sparse experimental evidence supporting this idea and we know little about the specific mechanisms behind any effect (Kadous \& Zhou, 2015). Research by Iskandar, et al., (2012), this study provides further evidence on the effect of motivational factors on auditors' performance. Understanding the mediating role of some motivational variables is crucial in designing a continuous development program to enhance auditors' performance.

Organizations may have different cultures such as corporate cultures that guide service and product quality, selection of distribution channels, advertising content and treatment of customers (Chadegani \& Jari, 2016). Work culture is a value system that is believed by members of the organization applied and 
developed continuously that serves as an adhesive system, and can be used as a reference to behave in the organization to achieve a defined organizational goals. Work culture can be a motivator, inspiring to always work better and satisfy all parties. Implementation of an effective work culture within the scope of local government can create a comfortable and conducive working environment, ultimately resulting in an achievement of organizational goals that are supported by optimal employee work. Research of (Alzeban, 2014) the cultural and economic contexts are underpinned by collectivism rather than individualism, it emerges that it is only comparatively recently that a tradition of governance and audit has started to develop, and that quite particular and strong cultural influences stemming from tribalism and pervasive core traditions beliefs operate to condition the effort to achieve the ideal internal audit environment. Research of (Pandoyo, 2016), organizational culture direcly and significantly effect on audit quality.

The leadership style is the attitude of a leader to influence his subordinates in working in such a way that the person is willing to execute the will of the leader in order to realize the desired organizational goals although personally it may not be liked. Leadership style of a leader is very influential on the performance of subordinates, in addition to get a good performance, the provision of learning to subordinates is required.

Independence is a state of mind that feels according to what is going on. An auditor must also have independence in conducting an audit in order to provide an opinion or conclusion without any influence from interested parties. The inspector must be objective and free from conflict of interest in carrying out his professional responsibilities. The examiner is also responsible for maintaining the independence in the mental attitude (independent in fact) and independence in the appearance of behavior. Research of (Rahmina \& Agoes, 2014), The results of this research show that in general auditor independence, audit tenure, and audit fee have a positive influence on audit quality.

A role difference between men and women is often referred to "gender" which often used in an agency. Gender is a social construct of differences in roles and opportunities between men and women. The differences in roles and opportunities exist both in family and community life, caused by the imaging of women and men. According to (Mulia, 2004), gender is a cultural concept used to distinguish the role, behavior, mentality and emotional characteristics between men and women who develop in society. Information plays an important role in decision making, especially in information processing. When compared with women, mainly men do not use all available information, so the results of their decisions are less comprehensive (Meyer \& Levy, 1986). Women's ability to get information is relatively more efficient than men. Women are also easier 
AKRUAL: Jurnal Akuntansi, volume 10, issue 2, April 2019 (105-118)

to receive new information and process it more sharply. This argument is supported by the research results from (Breesch \& Branson, 2009) the findings suggest that women auditors discover more potential misstatements than male auditors, though they analyze the misstatements in a less accurate manner than male auditors. The findings also indicate that women auditors are more risk-averse than male auditors.

This research was conducted at the Buleleng Inspectorate, Denpasar Inspectorate and Inspectorate of Bali Province. The selection of Inspectorate's office is due to its large supervision area with high regional expenditure budget. Based on the information of the representative of the Financial and Development Supervision Agency (Badan Pengawasan Keuangan dan Pembangunan (BPKP)) in Bali Province shows that on the Bali region, there were 21 cases of budgetary irregularities recorded in the form of corruption with the state losses value reached approximately $\mathrm{Rp} \mathrm{17,02}$ billion and more. The data was revealed based on the audit result of Financial and Development Supervision Agency of Bali Province Representative in charge of Bali and NTB Province. All these findings are the results of an audit of deconcentrated funds in a number of ministries, agencies, on the audit of procurement of government goods and services, audits of PNPM Mandiri government program implementation, and audit of BUMD. This poses a threat to whether the level of professionalism in the internal auditors of government auditors is appropriate or not. Where there are problems related to the performance of the auditor is the lack of auditor's own inspectorate findings because there are still many audit findings that are not detected by the inspectorate apparatus as the internal auditor.

Research by Putri \& Suputra (2013) shows that independence, professionalism and professional ethics have a positive effect on an auditor performance. (Kurnia, 2016) did research on the direct effect of ethics, education, experiance and motivation, and also significant effect of ethics, education, and experiance on the auditor's internal professionalism with motivation as intervening variable. Result of this study give evidence that ethics and education have effect on motivation. Ethics and education have effect on auditor's internal professionalism through motivation. But, experiance have no significant effect on motivation and also have no significant on auditor's internal professionalism through motivation. Research by Fujianti, et al., (2017) professionalism and auditor's performance: an analysis of gender perspective. The result of the research shows that there are influence of both variables on the performance of the male and female auditors, and there are differences in the influence of both variables on the performance between the male and female auditors. Research by Yan \& Xie (2016) The result of the research shows that there is no pervasive deterioration in audit quality resulting from auditor work stress; there is a significant negative association between work stress and audit quality in the initial audits of new clients; and the perception of work stress depends on

Copyright @ 2019 AKRUAL: Jurnal Akuntansi 
auditor's individual characteristics. Research by Abdolmohammadi (2012) The results show that while leadership attributes increase in importance by professional rank, technical skills generally decrease in importance by professional rank. Research by Bobek, et al. (2015), the results show that male participants' professional experience influences their ethical decision making, as auditors are less likely than tax professionals to recommend conceding to the client and to indicate that they would concede when faced with a contentious client issue. Research by Setiawan (2018) the study explored differences in auditors' judgments between male and female auditors working at public accounting firms in Indonesia. This study failed to find support for the prediction of gender socialisation theory, as the finding indicated that both male and female auditors made similar types of judgments. Research by Dali \& Mas'ud (2014), the research results indicated that auditors' professionalism can increase job satisfaction. Similarly, locus of control has significant effect to job satisfaction of auditors. High job satisfaction will improve significantly the auditors' performance. Most APIP perceived that performance achievement had not been good in quantity. There was still a tendency to delay the work that resulted in the finishing of a number of auditing assignment to be late, particularly related to finishing the report of examination result (LHP) BPK RI. This study was limited to respondents' perception on their activity as internal control officers. It did not examine the antecedent of professionalism variable that the practical implication of the development of professional attitudes and behaviors cannot be done comprehensively. Resarch by Darwanis, et al. (2016), the results showed that: simultaneously competency, professionalism, competence, financial management knowledge, and intensity of guidance influence the quality of the financial reporting area; professionalism, competence, knowledge of financial management, the intensity guidance apparatus, has partially affects the quality of financial reporting area. Research by Lesmana \& Machdar (2015), the result shows there are effect professionalism, competence and independence towards audit quality.

\section{LITERATURE REVIEW}

Motivation is a self-motivated condition of a targeted employee to achieve organizational goals. Mental attitude is a mental condition that encourages employees to work to achieve maximum performance. According Mangkunegara (2010) argues that there is a positive relationship between achievement motive and achievement of performance. Achievement motive is an impetus in the employee to perform an activity or tasks as well as possible in order to be able to achieve work performance with a commendable predicate. Cahyani, et al. (2015) indicated that: auditor's professional ethics, professionalism, motivation, working culture, and level of education had a 
AKRUAL: Jurnal Akuntansi, volume 10, issue 2, April 2019 (105-118)

partially and simultaneously significant and positive effect on the junior auditor's performances. The motivation of the junior auditor encourages the junior personal auditor to perform certain activities to achieve a goal of good audit quality.

$\mathbf{H}_{1}$ : Motivation has a positive and significant impact to the government auditors professionalism;

Organizational culture (work) is a system of values that all members of the organization believe and which are studied, applied, and developed continuously, serve as an adhesive system, and can be used as a reference to behave in the organization to achieve organizational goals that have been established (Cahyani et al., 2015). A degenerate culture will have a negative impact on organizational performance. Although culture is relatively difficult to change, but organizational culture can be created to further improve performance. (Cahyani et al., 2015) stated the organizational culture has a positive and significant influence on the performance of junior auditors.

$\mathbf{H}_{2}$ : Working Culture has a positive and significant impact to the government auditors professionalism;

Leadership style deals with the ways that managers use to influence their subordinates. The style of leadership is the norm of behavior a manager uses when he influences his subordinate's behavior. If the leadership takes place in a particular formal organization, where managers need to develop employees, build a climate of motivation, execute manejerial functions in order to produce high performance and improve company performance, managers need to adjust their leadership style (Trisnaningsih, 2001). According to (Wibowo, 2009) showed that a positive relationship between leadership style and auditor performance. It means the better way to lead a leader where the auditor works will further affect the auditor's performance. It can be concluded that there is a relationship between leadership style and auditor performance, that an auditor led by a leader who has a good lead and preferred by his subordinates then he will feel happy in working so that his performance will increase. Leadership style $\left(\mathrm{X}_{3}\right)$ is a way of leadership to influence other people in such a way that the person will do the will of the leader to achieve the goals of the organization although personally it may not be liked (Luthans, 2002).

$\mathbf{H}_{3}$ : Leadership style has a positive and significant impact to the government auditors professionalism;

Gender becomes one of the most important variables that relate to auditor performance. According to Meyer \& Levy (1986), Decision making by men is not comprehensive as is done by women who tend to be more detailed. In addition, women also have a sharper memory of new information than men and so the ability to process information becomes a little sharper. This argument is supported by research results from Cahyani et al. (2015); Breesch \& Branson (2009); Fujianti et al. (2017) and Setiawan (2018). Gender $\left(\mathrm{X}_{4}\right)$ is a cultural concept that seeks to make a difference 
in the aspects of role, behavior, mental and emotional characteristics between men and women in society. Differences in traits between women and men create different behavioral intentions and thinking patterns. Gender is a dummy variable in which $1=$ female and $0=$ men (Koes \& Januarti, 2011).

$\mathbf{H}_{4}$ : Gender has a positive and significant impact to the government auditors professionalism;

Independence is a state of mind that feels according to what is going on. An auditor must also have independence in conducting an audit in order to provide an opinion or conclusion without any influence from interested parties (Badan Pengawasan Keuangan dan Pembangunan, 2008). The inspector must be objective and free from conflict of interest in carrying out his professional responsibilities. The examiner is also responsible for maintaining the independence in the mental attitude (independent in fact) and independence in the appearance of behavior.

$\mathbf{H}_{5}$ : Independence has a positive and significant impact to the government auditors professionalism;

\section{RESEARCH METHODS}

This research is an explanatory research which is a study that seeks for the influence of certain variables against other variables in tightly controlled conditions which has causal relationships (Sugiyono, 2014). The subjects of this study were all auditors at the Inspectorate of Buleleng Regency, Inspectorate of Denpasar
City and Inspectorate of Bali Province. While the object of this study were Motivation, Work culture, Leadership Style, Gender, and Independence to the professionalism of government auditors. Types of data used was quantitative data, while the data collected by using questionnaires. Data analysis method used were validity and reliability test, classic assumption test, hypothesis test using $\mathrm{F}_{\text {-test }}$ analysis and $\mathrm{t}_{\text {-test }}$ test analysis then analyzed using multiple linear regression analysis. All the variables in this study were measured using the likert scale 1-5. The answers obtained will be scored by the criteria of the score (1) for the strongly disagreeable answer, the value (2) for the answer does not agree, the value (3) for the neutral answer, the value (4) for the agreed answer and the value (5) for answer strongly agree (Ghozali, 2011).

The general equation of multiple linear regression in this study is as follows.

\section{$\mathbf{P}=\alpha+\beta_{1} \mathrm{M}+\boldsymbol{\beta}_{2} \mathrm{WC}+\boldsymbol{\beta}_{3} \mathrm{LS}+\boldsymbol{\beta}_{4} \mathbf{G}+\boldsymbol{\beta}_{5}$ $\mathbf{I N}+\boldsymbol{\varepsilon}$}

Information :

\begin{tabular}{|c|c|}
\hline $\mathrm{Y}$ & $=$ Professionalism $(\mathrm{P})$ \\
\hline$\alpha$ & $=$ Constanta \\
\hline$\beta_{1,2,3,4,5}$ & $\begin{array}{l}=\text { coefficient regression of } \\
\text { independent variable }\left(X_{1}, X_{2}, X_{3} \text {, }\right. \\
\left.X_{4}, X_{5}\right)\end{array}$ \\
\hline $\mathrm{X}_{1}$ & $=$ Motivation $(\mathrm{M})$ \\
\hline $\mathrm{X}_{2}$ & $=$ Working Culture $(\mathrm{WC})$ \\
\hline $\mathrm{X}_{3}$ & $=$ Leadership Style (LS) \\
\hline $\mathrm{X}_{4}$ & $\begin{array}{l}=\text { Gender; } 1=\text { woman dan } 0= \\
\operatorname{man}(\mathrm{G})\end{array}$ \\
\hline $\mathrm{X}_{5}$ & $=$ Independence $(\mathrm{IN})$ \\
\hline & $=$ Error \\
\hline
\end{tabular}


AKRUAL: Jurnal Akuntansi, volume 10, issue 2, April 2019 (105-118)

Determination of coefficient analysis $\left(\mathrm{R}^{2}\right)$ is the percentage of influence between independent variables to dependent variables.

\section{ANALYSIS AND DISCUSSION}

\section{Descriptive statistics}

The deviation standard score is lesser than the mean score which indicates that the score distribution of Motivation, Working Culture, Leadership Style, Gender, Independence, and Professionalism is closer to the mean score, which indicates the response to these variables does not vary.

\section{Data Quality Test}

Based on the results from the questionnaires that had been distributed to 30 respondents, then the reliability and validity test were conducted. The validity test shows that the value of Sig. $(2$-tailed is less than 0.05 with the Pearson Correlation score is greater than $0.3494\left(\mathrm{r}^{-}\right.$table score for $\mathrm{n}=$ 30) as a valid requirement so that it can be said that the variable instrument is a valid to be used. Based on the results of reliability testing shows that the value of Cronbach's Alpha is greater than 0.7 , so it can be concluded that the instruments forming a variable is reliable.

\section{Classic Assumption Test}

Based on the table of SPSS output, shows the value of Asymp. Sig. (2-tailed) of 0.317 and not significant at $0.05(0.317>0.05)$ indicates that the residuals are normally distributed so that the later regression model is made acceptable and can be further analyzed.

The results of Multicolonierity test show that the tolerance values are above the value of
0.10 and the VIF value is below 10. This indicates that in the regression model there is no multicolonierity.

Based on the results of heteroscedasticity test, it appears that the five variables have Sig value. $>0.05$, so it can be concluded that there are no symptoms of heteroscedasticity. To test the hypothesis whether it is accepted or not, it will be tested by using the $t_{\text {-test. }}$ Based on the results of the analysis, the calculation will be done to compare between $\mathrm{t}_{-}$-ount value with $\mathrm{t}$-table . In this study used $\alpha$ (error rate) $=5 \%$. The result shows that the significance level of the five variables is $<0.05$ which means that $\mathrm{H}_{\mathrm{a}}$ is acceptable and $\mathrm{H}_{\mathrm{o}}$ is rejected so that the Motivation, Working Culture, Leadership Style, Gender, and Independence variables have positive and significant effect on Professionalism.

Based on the results of the data processing in this study, multiple linear regression equation is as follows.

\section{$\mathrm{P}=17,483+0,638 \mathrm{M}+0,116 \mathrm{WC}+0,059 \mathrm{LS}+$ $1,192 \mathrm{G}+0,089 \mathrm{IN}+\varepsilon$}

From the multiple linear regression equation mentioned above, it can be seen that:

1. The constant value for professionalism is 17,483 , this means that if independent variable is constant or fixed then professionalism is fixed that is equal to 17,483 .

Copyright @ 2019 AKRUAL: Jurnal Akuntansi 
2. The regression coefficient of Motivation variable is 0,638 and is marked as positive. This means that if there is an increase in the auditor's Motivation of 0.638 , it will lead to increased in auditor professionalism.

3. The regression coefficient of Working Culture variables is 0.116 and is marked as positive. This means that if there is an increase in Working Culture auditor of 0.116 , it will lead to increase in auditor professionalism.

4. The regression coefficient of the Auditor Leadership Style variable is 0.059 and is marked as positive. This means that if there is an increase in auditor leadership style of 0.059 , it will lead to increased in auditor professionalism.

5. The regression coefficient of the Gender variable is 1.192 and is marked as positive. This means that if there is a gender increase of 1,192 , it will lead to an increase in auditor professionalism.

6. The regression coefficient of the auditor independence variable is 0.089 and is marked as positive. This means that if there is an increase in auditor independence of 0.089 , it will lead to increased in auditor professionalism.

Based on the calculation of determination analysis with the help of SPSS 21.0 program, then the result is the value of coefficient of determination can be seen from Adjusted $\mathrm{R}$ square value of $41.1 \%$. This means that Motivation $\left(\mathrm{X}_{1}\right)$, Working Culture $\left(\mathrm{X}_{2}\right)$,
Leadership Style $\left(\mathrm{X}_{3}\right)$, Gender $\left(\mathrm{X}_{4}\right)$, and Independence $\left(\mathrm{X}_{5}\right)$ affect Professionalism $\left(\mathrm{X}_{6}\right)$ of $41.1 \%$ and the rest of it which is $58.9 \%$ influenced by other factors.

The discussion of the influence of each independent variable on the dependent variable is described as follows:

\section{The effect of Motivation on Government} Auditor Professionalism

Hypothesis 1 is accepted. The result of this research is consistent with Iskandar et al., (2012) researches which state that the motivation of employees in an organization as the dominant factor in encouraging employees to work well and produce maximum performance. Research by Daryatmi (2005) states that with the provision of motivation to employees both in the form of financial and non financial motivation is very influential on employee productivity. Motivation that is in a person's auditor is needed to encourage the improvement of performance and professionalism.

\section{The effect of Working Culture on Government Auditor Professionalism}

Hypothesis 2 is accepted. Empirically, the results of this study are consistent with the research by Alzeban (2014) and Farooqi, et al. (2017). The values contained in the Working culture should be implemented for the sake of life together in the organization and organizational goals so that later will affect the behavior and perform the work performance and professionalism of employees. 
AKRUAL: Jurnal Akuntansi, volume 10, issue 2, April 2019 (105-118)

The effect of Leadership Style on Government Auditor Professionalism

Hypothesis 3 is accepted. The results of this study are in line with Wibowo (2009), but not in line with (Widiyanto \& Yuhertian, 2015). Leadership style is a behavioral norm that a manager uses when he influences his subordinate's behavior. A person who performs a management function is obliged to influence the employees below him in order to keep performing their duties properly, have a dedication to the organization and obliged to achieve the organizational goals (Sedarmayanti, 2008).

The effect Gender on Government Auditor Professionalism

Hypothesis 4 is accepted. The results of this study are in line with research by Kusumayanti (2014) and Breesch \& Branson (2009). Gender is the role difference between men and women who demand harmony so as to achieve maximum performance. Women generally have a higher level of moral judgment than men (Jamilah, et al. (2007). In terms of decision making, a moral consideration is needed especially in the audit of client companies. this distinguishes between women and men (Meyer \& Levy, 1986). Women are easier to get access to information because they tend to have sharper memories and caution in processing information.

The effect of Independence on Government Auditor Professionalism

Hypothesis 5 states that Independence has a positive and significant effect on government professionalism is accepted. Results of this study are consistent with research by Lesmana \& Machdar (2015); Rahmina \& Agoes (2014); Putri \& Suputra (2013). Being independent means avoiding relationships that can interfere with the mental attitude and objective appearance of the auditor in conducting the audit.

\section{CONCLUSIONS}

Based on the results of research and discussion that has been described before, the conclusions that can be drawn from this research are: Motivation, Working Culture, Leadership Style, Gender, and Independence have positive and significant impact on the professionalism of the government auditor, with a significance level of $5 \%$. An internal government auditor should improve his professionalism for the efficiency and effectiveness improvement in order to improve public sector performance. The function of internal auditors in performing internal audit function which is an independent assessment function within an organization to test and evaluate the activities of the organization undertaken. Professionalism is needed to improve the quality of the audit in order to prevent, detect, and reveal fraud. Professionalism is a mental attitude in the form of commitment from members of a profession to always realize and improve the professional quality. The auditor is obligated to carry out its examination duties based on audit standards that have been established so that the quality of audit results can be accounted for. Auditors who have adherence to the code of ethics will carry out the

Copyright @ 2019 AKRUAL: Jurnal Akuntansi 
audit process correctly and affect the quality of the results of the examination.

\section{REFERENCES}

Abdolmohammadi, M. J. (2012). Chief Audit Executives Assessment of Internal Auditors' Performance Attributes By Professional Rank And Cultural Cluster. Behavioral Research In Accounting, 24(1), $1-23$.

Alzeban, A. (2014). The Impact Of Culture on The Quality Of Internal Audit An Empirical Study. Journal Of Accounting, Auditing \& Finance, 30(1), 57-77.

Badan Pengawasan Keuangan Dan Pembangunan. (2008). Manajemen Pengawasan Stratejik (Edisi Ketiga). Bogor: Pusdiklatwas BPKP.

Bobek, D. D., Hageman, A. M., \& Radtke, R. R. (2015). The Effects Of Professional Role, Decision Context, and Gender On The Ethical Decision Making Of Public Accounting Professionals. Behavioral Research In Accounting, 27(1), 55-78.

Breesch, D., \& Branson, J. (2009). The Effects of Auditor Gender On Audit Quality. Accounting Research \& Audit Practices, VIII (3 \& 4), 79-107.

Cahyani, K. C. D., Purnamawati, I. G. A., \& Herawati, N. T. (2015). Pengaruh Etika Profesi Auditor, Profesionalisme, Motivasi, Budaya Kerja, dan Tingkat Pendidikan Terhadap Kinerja Auditor Junior (Studi Empiris Pada Kantor Akuntan Publik Di Bali). E-Journal S1 Ak Universitas Pendidikan Ganesha, 3(1).

Carlson, D., Cowen, J. M., \& Fleming, D. (2013). Third-Party Governance and Performance Measurement: A Case Study Of Publicly Funded Private School Vouchers. Journal Of Public Administration Research And Theory, 25, 897-922.

Chadegani, A. A., \& Jari, A. (2016). Corporate Ethical Culture: Review Of Literature and Introducing PP Model. In Procedia Economics And Finance (Pp. 51-61). Sciencedirect-Elsevier.
D’Onza, G., \& Sarens, G. (2018). Factors That Enhance The Quality of The Relationships Between Internal Auditors and Auditees: Evidence From Italian Companies. International Journal Of Auditing, 22, 112.

Dali, N., \& Mas'ud, A. (2014). The Impact Of Professionalism, Locus Of Control, and Job Satisfaction On Auditors' Performance: Indonesian Evidence. International Journal Of Business And Management Invention, 3(10), 63-73.

Darwanis, D., Saputra, M., \& Kartini, K. (2016). Effect Of Professionalism, Competence, Knowledge Of Financial Management, and Intensity Guidance Apparatus Inspectorate For Quality Of Financial Statements (Study On Inspectorate Regencies/Cities In Aceh). BRAND. Broad Research In Accounting, Negotiation, And Distribution, 7(1), 28-36.

Daryatmi. (2005). Pengaruh Motivasi, Pengawasan dan Budaya Kerja Terhadap Produktivitas Kerja Karyawan Perusahaan Daerah Bank Perkreditan Rakyat Badan Kredit Desa Kabupaten Karanganyar.

Farooqi, S., Abid, G., \& Ahmed, A. (2017). How Bad It Is To Be Good: Impact of Organizational Ethical Culture on Whistleblowing (The Ethical Partners). Arab Economic And Business Journal, 12(2), 69-80.

Fujianti, L., Tabroni, \& Rais, H. (2017). Professionalism and Auditor's Performance: An Analysis Of Gender Perspective. IOSR Journal Of Economics And Finance (IOSR-JEF), 8(6), 43-52.

Ghozali, I. (2011). Aplikasi Analisis Multivariate dengan Program SPSS (5th Ed.). Semarang: BP Universitas Diponegoro.

Herawaty, A., \& Susanto, Y. K. (2009). Pengaruh Profesionalisme, Pengetahuan Mendeteksi Kekeliruan, dan Etika Profesi Terhadap Pertimbangan Tingkat Materialitas Akuntan Publik. In Jurnal Akuntansi Dan Keuangan (Vol. 11, Pp. 1320). 
Hussin, S. A. H. S., Iskandar, T. M., Saleh, N. M., \& Jaffar, R. (2017). Professional Skepticism and Auditors' Assessment Of Misstatement Risks: The Moderating Effect Of Experience And Time Budget Pressure. Economics And Sociology, 10(4), 225250.

Iskandar, T. M., Sari, R. N., Mohd-Sanusi, Z., \& Anugerah, R. (2012). Enhancing Auditors' Performance: The Importance Of Motivational Factors And The Mediation Effect Of Effort. Managerial Auditing Journal, 27(5), 462-476.

Jamilah, S., Fanani, Z., \& Chandrarin, G. (2007). Pengaruh Gender,Tekanan Ketaatan dan Kompleksitas Tugas Terhadap Audit Judgment. In Simposium Nasional Akuntansi X. Makasar: Universitas Hasanudin.

Kadous, K., \& Zhou, Y. (Daniel). (2015). How Does Intrinsic Motivation Improve Auditor Judgment in Complex Audit Tasks?, 46, Https://Papers.Ssrn.Com/Sol3/Papers.Cfm? Abstract_I.

Koes, S., \& Januarti, I. (2011). Pengaruh Pengalaman, Keahlian, Situasi Audit, Etika dan Gender Terhadap Ketepatan Pemberian Opini Auditor Melalui Skeptisme Profesional Auditor (Studi Kasus Pada KAP Big Four Di Jakarta). Semarang.

Kurnia, A. (2016). Pengaruh Etika, Pendidikan dan Pengalaman Terhadap Profesionalisme Auditor Internal Dengan Motivasi Sebagai Variabel Intervening. JOM Fekon, 3(1), 1190-1204.

Kusumayanti, P. T. (2014). Pengaruh Akuntabilitas, Pengetahuan Audit dan Gender Terhadap Kualitas Hasil Kerja Auditor Internal (Studi Pada Badan Inspektorat Kabupaten Buleleng Dan Kabupaten Bangli). E-Journal S1 Ak Universitas Pendidikan Ganesha, 2(1).

Lesmana, R., \& Machdar, N. M. (2015). Pengaruh Profesionalisme, Kompetensi, dan Independensi Auditor Terhadap Kualitas Audit. Kalbisocio (Jurnal Bisnis Dan Komunikasi), 2(1), 33-40.

Luthans, F. (2002). The Need For and Meaning Of Positive Organizational Behavior. Journal Of Organizational Behavior, 23(6), 695-706.
Mangkunegara, A. P. (2010). Evaluasi Kinerja SDM. Bandung: PT Revika Aditama.

Mcclelland, D. C. (1987). Human Motivation (I). New York, United State Of America: Cambridge University Press.

Meyer, \& Levy, J. (1986). Gender Differences In Information Processing: A Selectivity Interpretation. In Cognitive and Affective Responses To Advertising. (C. P. \& M.Tybout, Eds.). Lexington: MA: Lexington Books.

Mulia, S. M. (2004). Islam Menggugat Poligami. Jakarta: Gramedia Pustaka Utama.

Norgren, C. (2010). The World Needs International Audit Standards. International Journal Of Government Auditing, 37(1), 145.

Pandoyo. (2016). The Effect Of Auditor Competence, Independence, Audit Experience, Organizational Culture And Leadership Against Auditor Professionalism And Its Implication On Audit Quality. International Journal Of Advanced Research, 4(5), 1632-1646.

Putri, K. M. D., \& Suputra, I. D. G. D. (2013). Pengaruh Independensi, Profesionalisme, Dan Etika Profesi Terhadap Kinerja Audior Pada KAP Di Bali. E-Jurnal Akuntansi Universitas Udayana, 4(1), 39-53.

Rahmina, L. Y., \& Agoes, S. (2014). Influence Of Auditor Independence, Audit Tenure, And Audit Fee On Audit Quality Of Members Of Capital Market Accountant Forum In Indonesia. In Procedia - Social And Behavioral Sciences (Pp. 324-331).

Rutherford, A. (2014). Organizational Turnaround And Educational Performance: The Impact Of Performance-Based Monitoring Analysis Systems. American Review of Public Administration, 44(4), 440-458.

Santosa, M. H., Maarif, M. S., Eriyatno, \& Andati, T. (2016). System Analysis In Developing An Effective Government Internal Audit System. International Journal On Advanced Science Engineering Information Technology, 6(2), 153-160.

Sedarmayanti. (2008). Manajemen Sumber Daya Manusia (Reformasi Birokrasi Dan Manajemen Pegawai Negeri Sipil) (Kedua). Bandung: PT. Refika Aditama. 
Setiawan, W. Y. (2018). Gender Differences In Auditors' Judgments: Evidence From Indonesia. Review Of Integrative Business And Economics Research, 7(1), 350-358.

Soh, D. S. B., \& Martinov-Bennie, N. (2011). The Internal Audit Function: Perceptions of Internal Audit Roles, Effectiveness And Evaluation. Managerial Auditing Journal, 26(7), 605-622.

Sugiyono. (2014). Metode Penelitian Kuantitatif Kualitatif dan R\&D. Bandung: Alfabeta.

Trisnaningsih, S. (2001). Pengaruh Komitmen Terhadap Kepuasan Kerja Auditor: Motivasi Sebagai Variabel Intervening (Studi Empiris Pada Kantor Akuntan Publik di Jawa Timur). Jurnal Riset Akuntansi Indonesia, 6(2), 199-216.

Wibowo, H. A. O. (2009). Pengaruh Independensi Auditor, Komitmen Organisasi, Gaya Kepemimpinan, dan Pemahaman Good Governance Terhadap Kinerja Auditor (Studi Empiris Pada Kantor Akuntan Publik Di Daerah Istimewa Yogyakarta).

Widiyanto, A. K. D., \& Yuhertian, I. (2015). Pengaruh Pendidikan, Pengalaman dan Pelatihan Terhadap Profesionalisme Auditor Pemerintah Yang Bekerja Pada Badan Pengawas Kota Surabaya. In Konferensi Nasional Akuntansi. Jakarta.

Yan, H., \& Xie, S. (2016). How Does Auditor's Work Stress Affect Audit Quality? Empirical Evidence From The Chinese Stock Market. China Journal Of Accounting Research, 9, 305-319. 
AKRUAL: Jurnal Akuntansi, volume 10, issue 2, April 2019 (105-118) 